Pavel Stůj

Palacký University Olomouc

\title{
Infanticide and the Conflicts in Early Modern South Bohemia (169o-1710). Five Women from Jindřichův Hradec ${ }^{1}$
}

According to the Cambridge Dictionary, social conflict is defined as "an active disagreement between people with opposing opinions or principles" and also as "fighting between two or more groups of people or countries." Nevertheless, there are many different approaches to the theory of conflicts in the traditional sociology. According to the idea of social stratification, the society can be defined as a juxtaposition of social strata with opposing opinions, which were described either as the class struggle (Karl Marx) or as other types of tension like ethnic or religious one (Max Weber). The concept of conflict is essential for both: "Marx thinks it is quite conceivable that when the emancipation of the proletariat is ensured society will be rid of conflict, whereas Weber is sceptical and does not believe in the disappearance of conflict."3 Other sociologists (Spencer) consider struggle as a normal part of social life. Conflict is a factor of progress (evolution) of the society and therefore a normal form of the human behaviour connected with natural selection. ${ }^{4}$

1. The article was written by dint of the grant MŠMT, grant IGA_FF_2018_006 Společnost v historickém vývoji od středověku po moderní věk IV.

* "Příspěvek vznikl za podpory MŠMT, grant IGA_FF_2018_006 Společnost v historickém vývoji od středověku po moderní věk IV."

2. The Cambridge dictionary, see: https://dictionary.cambridge.org/dictionary/english/conflict (29.09.2018).

3. M. Wieviorka, Social Conflict, "Current Sociology" 61 (2013) 5-6, p. 697.

4. M. Wieviorka, Social Conflict, op. cit., p. 698. 
However, these theories had been put together in further analyses (like the one proposed by Georg Simmel). ${ }^{5}$ Conflict can be described as that what happens when interests of individuals or groups are antagonistic and in conflict of status or power. It is not only a struggle between classes, ethnical groups or war parties, but at the same time a relationship between opponents who partially share cultural references. It is a process in which individuals are seeking to obtain rewards by eliminating or weakening their competitors. Therefore, according to Simmel, we can distinguish among four types of conflicts (war, feud or fictional strife, litigation, conflict of impersonal ideals) ${ }^{6}$ These types of conflicts, as this paper demonstrates, are the constituent part of the infanticide phenomenon as well.

Sociological theories offer a tool to analyse the social historical phenomenon like infanticide in the early modern history. Consequently, infanticide can be seen both as the result of the intrapersonal conflict (to be or not to be a mother) and the interpersonal, social conflicts (disagreement between the society and the perpetrator of infanticide who had a different opinion about matehood).

Early modern sources, e.g. broadsheets or broadside ballads, describe many types of conflict situations in infanticide cases. Authors of these news describe infanticide as a problem of unmarried mothers (lewd women in Christian society). Similarly, impersonal conflicts were depicted in the pamphlets and broadsheets. These sources document confessional conflicts like struggles between Catholics and Protestants in different regions. Finally, personal accusations, antipathy and conflict between members of the family or sexual partners can be found in interrogation proceedings as well. Events forgoing the crime are based on disagreements, violence and verbal abuse. The contextual analysis of conflicts in five South Bohemian infanticide proceedings $(1690-1710)$ will be the centre of the second part of this paper.

The aim of this paper is to analyse relationship between the institution of motherhood (as a social construct which is variable in time), its symbolic and cultural meanings and common thoughts about mothering (mothering duties, maternal instinct, affection, love, bond and care). ${ }^{7}$ In this regard,

5. See: G. Simmel, The Sociology of Conflict I, "American Journal of Sociology" 9 (1903), pp. $490-525$.

6. See: G. Simmel, The Sociology of Conflict I, op. cit, pp. 490-525.

7. More about motherhood and mothering in: E. Jeremiah, Murderous Mothers. Adrienne Rich's Of Woman Born and Toni Morrison's Beloved, in: From Motherhood to 
pamphlets can show us, how authors' arguments were constructed and how the gender of honest mother was described. The case study from the south Bohemian region can depict, how these women acted in real situations and what were their notions of motherhood.

There were not only loving, passive and selfless mothers in early modern period, but we can also find many women, who refused this social role, who were not prepared for being mothers. They were trapped in situations with the motherhood not a reasonable option. As Italian philosopher Caesare Beccaria (1769) mentioned, this conflict between motherhood and mothering required a choice between shame the murder: "The murder of bastard child is [...] the effect of a cruel dilemma, in which a woman finds herself who has been seduced through weakness or overcome by force. The alternative is, either her own infamy, or the death of a being, who is incapable of feeling the loss of life."8

\section{Infanticide and the early modern European society}

The term infanticide has been attributed to the crime of killing the newborn child by its own mother. It is a complex phenomenon which is possible to trace to prehistoric era. This practice had been used for reduction of offspring numbers (especially female babies), elimination of handicapped children (Sparta) or as a prevention of poverty (Aristotle, Plato). From an evolutionary perspective, infanticide can be understood as a common custom in "traditional societies." 9

Nevertheless, the Christian religion was based on the protection of children (as the Church Father Tertullian and many Church authorities mentioned): Christian woman should have protected her offspring by the cost

Mothering: The Legacy of Adrienne Rich's Of Woman Born, ed. A. O'Reilly, New York 2004, pp. 59-71.

8. C. Beccaria, An Essay on Crimes and Punishments, London 17692, pp. 131-132.

9. About evolutional perspective see more: S. B. Hrdy, Mother Nature. A history of mothers, infants, and natural selection, New York 1999, p. 296-297; L. Williamson, Infanticide: An Anthropological Analysis', in: Infanticide and the Value of Life, ed. M. Kohl, New York 1978, p. 61; M. Obladen, From Right to Sin: Laws on Infanticide in Antiquity, "Neonatology" 109 (2016), p. 56-61; M. Obladen, From Sin to Crime: Laws on Infanticide in the Middle Ages, "Neonatology" 109 (2016), p. 8590; M. Obladen, From Crime to Disease: Laws on Infanticide in the Modern Era, "Neonatology" 109 (2016), p. 170-176. 
of her own life, she ought to nurture her baby and bring it up. ${ }^{10}$ Many texts described motherhood virtues, e.g. self-sacrifice, solicitude, economic and social responsibility etc. Obviously, crimes as infanticide or abortion had been strictly prosecuted since the medieval period (as we know from sources like penitential books, late medieval chronicles or law treaties). ${ }^{11}$

Different opinions about infanticide in early modern period are held, as well as various causes and social conditions affected the crime. ${ }^{12}$ Infanticide in historiography is a collection of stories dealing with struggles and social conflicts. It is a conflict between innocent youth or naivety and lust, between the worlds of women and men, between future plans and reality of the false promises, and also a conflict between parents' authority and untamed youth. ${ }^{13}$ Stories of lawyers, surgeons or priests who had been struggling to understand this crime are also described. ${ }^{14}$

Obviously, it is not only the western scholarship who was dealing with infanticide in last three decades. There are at least three generations of Czech historians who were interested in this topic as well. Jaroslav Pánek and Eva Procházková did a detailed research in central Bohemia region in 1980's, hereafter historians analysed more criminal sources in the next decade ${ }^{15}$

10. See: Tertullianus, Apologeticum, chapter VIII and IX, online: http://www.tertullian.org/other/czech_apologeticum.htm (4.06.2018).

11. See: W. Müller, Die Abtreibung: Anfänge der Kriminalisierung 1140-1650, Cologne 2000; W. Müller, The Criminalization of Abortion in the West: Its Origins in Medieval Law, Ithaca 2012.

12. On infanticide in general see: P. Hoffer, N. Hull, Murdering Mothers: Infanticide in England and New England 1558-1803, New York 1981; Newborn Child Murder: Women, Illegitimacy and the Courts in Eighteenth-Century England, ed. M. Jackson, New York 1996; A. Kilday, A History of Infanticide in Britain, c. 160 o to the Present, Basingstoke 2013; Nature's Cruel Step-dames: Murderous Women in the Street Literature of Seventeenth Century England, ed. S. Staub, Pittsburgh 2005; R. van Dülmen, Frauen vor Gericht: Kindsmord in der Frühen Neuzeit, Frankfurt a.M. 1991; K. Michalik, Kindsmord, Sozial- und Rechtsgeschichte der Kindstötung im 18. und beginnenden 19. Jahrhundert am Beispiel Preußen, Pfaffenweiler 1997; O. Ulbricht, Kindsmord und Aufklärung in Deutschland, Munich 1990.

13. Here you can see: D. Myers, Death and a Maiden. Infanticide and the Tragical History of Grethe Schmidt, DeKalb 2011.

14. See: M. B. Lewis, Infanticide and abortion in early modern Germany, New York 2016; J. Harrington, The Unwanted Child: The Fate of Foundlings, Orphans, and Juvenile Criminals in Early Modern Germany, Chicago 2009; M. Boes, Crime and Punishment in Early Modern Germany: Courts and Adjudicatory Practices in Frankfurt am Main, 1562-16g6, Farnham 2013, pp. 145-179.

15. See: J. Pánek, Zločin „zahubení plodu” v Maršovicích roku 1682, "Český lid" 1979 no. 66, pp. 45-46; E. Procházková, Žena a smrt dítěte v soudní praxi raného novověku. 
and finally some of the contemporary historians adapted to modern historiographical methods (microhistory, gender history, historical anthropology) in their research. Especially, Jaroslav Čechura, Pavel Himl, Daniela Tinková and Jaroslav Dibelka wrote several case studies or monographs in which they partly focused on infanticide (in many cases in south Bohemia region as well).$^{16}$

Finally, infanticide was a conflict between the Christian idealistic view of the caring Mother (Virgin Mary) and independent single women, who rejected their offspring. Especially during the $16^{\text {th }}$ and $17^{\text {th }}$ century child murder was seen as a delicate problem of contemporary discourse; humanist writers as well as baroque preachers often mentioned dangerous wicked women, pitiful mothers following instructions of the devil and killing their innocent children. ${ }^{17}$ Even though it was still quite marginal crime, it was strictly

Edice a rozbor Čechtického útrpného vyznání z roku 1729, "Sborník vlastivědných prací Podblanicka" 1994 no. 34, pp. 115-128; J. Francek, Dějiny loupežnictva: zloději, loupežníci, lupiči, pytláci a žháři v českých dějinách, Praha 2002; J. Francek, Zločin a sex $v$ českých dějinách. Manželské spory a sexuální kriminalita v raném novově$k u$, Praha 2000. From the perspective of historical demography see more: A. Šubrtová, Kontracepce, aborty a infanticida $v$ pramenech $k$ predstatistickému období, "Historická Demografie" 15 (1991), pp. 9-46; A. Velková, Dítě jako obět'. Vraždy dětí spáchané jejich matkami ve 2. polovině 19. století, in: Od početí ke školní brašně. Sborník z odborného semináře konaného 29.-30. května 2008 ve Východočeském muzeu v Pardubicích, red. M. Halířová, Pardubice 2008, pp. 147-163; A. Luxová, Problém infanticidy ve vzorku trestanek v ženské trestnici v Řepích, "Historická Demografie" 29 (2005), pp. 139-200.

16. J. Čechura, Kriminalita a každodennost v raném novověku, Jižní Čechy 1650-1770, Praha 2008; J. Čechura, Sex v době temna, Praha 2015; J. Dibelka, Obranné strategie mužů a žen obviněných ze smilstva a cizoložství. Panství Třeboň na přelomu 17. a 18. Století, České Budějovice 2012; J. Dibelka, Tajemství rodiny Hlučných. Obranné strategie žen obviněných z infanticidia, "Dějiny a současnost" 9 (2007), pp. 37-39; J. Dibelka, Obranné strategie "zmrhaných" žen na jindřichohradeckém panství v 17. a na počátku 18. století, "Historická Demografie" 31 (2007), pp. 5-20; D. Tinková, Ilegitimita a "nová ekonomie života“ v osvícenské Habsburské monarchii. Problém svobodných matek a nemanželských dětí mezi sociální kontrolou a sociální péčí na prahu občanské společnosti, "Historická Demografie" 27 (2003), pp. 133-172; D. Tinková, Předcházet či trestat? Problém infanticidia v osvícenské společnosti, "Český časopis historický" 101 (2003), s. 27-76; D. Tinková, Hř́ch zločina šilenství v čase odkouzlování světa, Praha 2004; D. Tinková, Tělo, věda, stát. Zrození porodnice v osvícenské Evropě, Praha 2010.

17. For the Czech and German context of moralistic texts see e. g. "Leichenpredigt" by J. Sarius, Infanticidium Helmsdorffianum: Oder: Christliche Leichen- und Klagpredigt [...] Uber dem grausamen/ erschrecklichen und unerhörten Kinder Mordt/ So sich begeben in der Mühlen zu Helmsdorff, Dreßden 1633, VD17 3:634234H; Valuable is also the collection of early modern texts written by Czech moralists 
prosecuted and punishable by death in early modern Europe. A disobedience and sexual activity of young girls (lack of parental control) were the main reasons for many conflicts in infanticide cases.

There were only few significant roles which were assigned to women in that time: woman as a virgin, a wife or a widow. ${ }^{18}$ In this context, young servants and unmarried girls were subordinated to their fathers and employers (in terms of domesticity and patriarchy), but in a similar way also to their stepmothers and older sisters (as a stepdaughter and younger sister). Despite the certain equality between people of the same class (journeymen, their friends/co-workers), their ability to act on their own will was limited. In general, the pre-modern European model of kinship was supported by church and based on paternal, legitimate bloodline.

Consequently, infanticide was the result of the direct influence of the Christian society on the peers (women), who should have changed their attitudes towards motherhood. To illustrate this assumption, two types of sources will be analysed: popular literature and the interrogation proceedings.

\section{Infanticide and conflicts in early modern street literature}

The image of a bad mother and a disobedient wife appeared frequently in non-periodical early modern printed news. Infanticide as a matter of considerable public concern was highlighted in sources like broadside ballads or pamphlets. Because the institution of marriage was a key to the understanding of women's social position, many street literature narratives were based on conflicts between partners or child-parent relationship. ${ }^{19}$

in four volumes by: Nádoby mdlé, hlavy nemající?: diskursy panenství a vdovství $v$ české literatuře raného novověku?, edd. J. Ratajová, L. Storchová, Praha 2008; Žena není přišera, ale nejmilejší stvoření Boží: diskursy manželství v české literatuře raného novověku, edd. J. Ratajová, L. Storchová, Praha 2009; Žádná ženská člověk není: Polarizace genderů v českojazyčné literatuře 18. a 19. století, edd. J. Ratajová, L. Storchová, Praha 2010; Děti roditi jest Božské ovotce: gender a tělo v českojazyčné babické literatuře raného novověku, edd. J. Ratajová, L. Storchová, Praha 2013.

18. See: L. Storchová, Gender a "přirozený řád", in: Nádoby mdlé, hlavy nemající?, edd. J. Ratajová, L. Storchová, Praha 2008, pp. 510-530. For the case of Elisabeth see more: P. Stůj, Gender and Infanticide in Early Modern Bohemia: The Case of Elisabeth Symandlin, 1707-1710, "West Bohemian Historical Review" 8 (2018) no. 2, pp. 145-184.

19. More about street literature: M. Schilling, Bildpublizistik der frühen Neuzeit: Aufgaben und Leistungen des i1ustrierten Flugblatts in Deutschland bis zum 17oo, Tubingen 1990; K. te Heesen, Das illustrierte Flugblatt als Wissensmedium der 
In two pamphlets from the $17^{\text {th }}$ century, Pittilesse Mother (1616) and Bloody Newes from Dover (1647), ${ }^{20}$ two mothers (Catholic Margret Vincent and Anabaptist Mary Champion) decided that the murder is the only solution of their confessional conflicts and killed their newborn-children because they wanted to save them from being raised in heretical environment, for both their husbands were protestants.

Mary Champion (1647) cut off her son's head, just before he could have been baptized. Mary insisted that the baby should have a choice to receive the baptism and rather committed infanticide: „Behold husband, thy sweet babe without a head, now go and baptize it; if you will, you must christen the head without a body, for here they lye separated." Her husband John reacted, shocked: "O thou bloody and inhumane wretch, what hasle thou done." 21 Mary was imprisoned soon after that and later in the prison cell she has visions of her dead child.

Second woman, Margret Vincent (1616), killed her two children, because she was seduced by her Catholic friends (Roman wolves). This very offensive pamphlet was written as a warning before dangerous Roman Catholicism spreading in protestant England. The gentlewoman was turned into the "obstinate Papist." Her husband Jarvis desperately strived to stop her: „Oh Margret, Margret, how often have I persuated thee from this dammed Opinion, this dammed Opinion, that hath undone us all."22 But the devil was stronger, Margret was instructed to save her childrens' souls from the blindness of the protestant religion and she, as a "bloody Medea, not deserving the mothers name," killed all three of her children.

Both crimes in these stories are not only result of confessional conflict, but at the same time a rebellion against the patriarchal authority, because

Frühen Neuzeit, Opladen 2011; J. Wiltenburg, Crime and culture in early modern Germany, Charlottesville 2012.

20. G. Eld, A Pittilesse Mother: The at most vnnaturally at one time, murthered two of her owne children at Acton within sixe miles from London vppon holy Thursday, London 1616, Early English Books Online [EEBO], STC 24757; Anonym, Bloody Newes from Dover. Being a true relation of the great and bloudy murder, committed by Mary Champion, London, 1647, EEBO, Wing B3267.

21. Bloody Newes from Dover.

22. "For Having learned this maxim of their Religion, that it was meritorious yea and pardonable, to take away the lives of any opposing Protestants were it of any degree whatsoever, in which resolution or bloody purpose she long stood upon, and at last (only by the Devil's temptation) resolved the ruin of her own children." (A Pittilesse Mother, f. A3r.) 
women did not respect husband's wishes and religion preferences. They betrayed his trust and the whole community.

The third pamphlet, Blood for Blood (1670), ${ }_{1}^{23}$ is dealing with intrapersonal conflict (called by the general term "melancholy"). It is a story of the mentally ill woman, Mary Cook, who was being tempted by the devil. According to the author, her feelings of helplessness and her desire to commit suicide were behind her crimes. While her husband was gone, she murdered her newborn by cutting its throat. Again, a husband, the gentleman Mr. Cook protected his wife from the devil's temptation and he dealt with her problems for a long time, but when he had to leave one day, no one was able to stop his wife.

Finally, many examples of this criminality can be found in Czech and German broadsheets too. Maidservant Catharina von Limburg in Eine Warhafftige newe Zeittung (1626) ${ }^{24}$ was arrested after multiple child murders were discovered by the local law. For many years Catharina was living in illicit illegitimate relationships and she gave birth to six babies, all she murdered. On the woodcut we can see her committing these crimes at different public places like a latrine, a field or a wooden barn. Her wicked crimes were finally revealed by her parents, when she delivered twins in their house. Horrified parents revealed her crime to authorities. According to the author, all her evil deeds were results of the lax parental control, as they had sent her off to service too soon. Author also focuses on general criticism of the society, because crime of infanticide happened in large amount everywhere, like an avalanche, and no one was able to stop it. ${ }^{25}$

Many similar conflicts of different religion, social classes, or family members can be found in other Czech ballads and news. Besides the stories

23. N. Patridge, Blood for Blood or Justice executed for innocent Blood-shed. Being a True Narrative of that late Horrid committed by Mary Cook, London 1670, EEBO, Wing, P630.

24. Anonym, Eine Warhafftige vnd erschröckliche newe zeittung welche sich begeben vnd zugetragen hat in der Stadt Limmburg, Frankfurt am Main 1626 (printer Wolfgang Richter), Available in Germanisches Nationalmuzeum, Nürnberg, sign. HB24792.

25. Hilf Jesu Christ du Gottes Sohn, der du sißt in den höchsten Thron, lass dir den Jammerklagen, kein besserung mehr verhanden ist, man brauchet nur viel arger list, nach keiner Straff thut man mehr fragen. O mensch, o mensch, und bekehr dich frey, sey fromm und fürchte Gott dabey, so wistu Gnad erwerben, vnd mit Gott leben ewiglich, ererben das ewige himmelreich, darauff sprach ich frölich, amen." (Anonym, Eine Warhafftige...) 
of unjustly accused maidservant, who is alone against the society ${ }_{1}{ }^{26}$ there are also ballads with more traditional plot dealing with bad "raven" mothers, who want to escape their mothering duties. ${ }^{27}$

There is obvious moralistic aim of these songs about infanticide. The devil is originator of many of these sad stories. Deadly sins (alcoholism, gambling, fornication), disobedience and conflicts happened when the Christian were not vigilant and when they let the devil prevail in their souls. Usually, the devil is responsible for the all the evil in the world (Deus ex machina). The same character is depicted on the front page of the Pittilesse Mother pamphlet. The fallen angel is giving a rope to Margaret Vincent, which she later uses to strangle her son.

But if there is universal explanation for fictional crime stories, how this situation looks like in specific conditions of the early modern Bohemia criminal investigations?

\section{Interrogation proceeding from Jindřichův Hradec}

Likewise the fictional popular crime reports, the real early modern child-murder investigations were characterized by many conflicts and struggles on different levels of social organization. Sources deposited in State District Archive in Jindřichův Hradec (former South Bohemian town Neuhaus) show the proceedings, how the city magistrate and representatives of the estate owner negotiated criminal accusations, how bad mothers were interrogated or what interpersonal conflicts influenced the crime. ${ }^{28}$

26. Anonym, Dwoge Nowiny: Prwnij Co se w Městě Losanně w Zemi Ssweycarské ležjcým y při giných Městech, Praha 1589, Knihopis Ko6486, online: http:// www.manuscriptorium.com/apps/index.php?direct=record\&pid=AIPDIG-KCR__65_E_2031___49PG508-cs\#search (30.03.2019).

27. Anonym, $\bar{M}$ ord ukrutný, který se stal v kraji brněnském. Muzem Komenského v Přerově, sign. J-2698; Anonym, Nová píseň, Okolo Dunaje chodila, krásné pachole nosila. Knihovna národního muzea (KNM), sign. A 2574; Anonym, Nová píseñ o jedné bohaprázdné panně. KNM, sign. KP 3838; Anonym, Nová píseñ. Krkavčí matka. Hrozná vražda malé Růženky. KNM, sign. KP D 34/1.

28. State District Archive of Třeboň: branch office Jindřichův Hradec, in the collection of estate of J. Hradec (fond Velkostatek J. Hradec), Crimes (Zločiny), sign. VBC, cardboard 413-417. In Czech: Státní okresní archiv Třeboň, pobočka Jindřichův Hradec, fond Velkostatek Jindřichův Hradec, signatura VBC (zločiny), inventátní číslo 4358-4360, karton 413-417. (There you can find five cases further referred to as "Elisabeth", "Mariana Filipová", "Mariana Dalšovská", "Eva Mikšová" or "Voršila Králová"). 
The conflict between legal norm and daily practice was one of many problems of the early modern law. While contemporary law codes were prescribing capital punishment for infanticide, there were only few executions in early modern praxis. Judges' decisions were regulated by the estate office and by Superior Court of Appeal (Appelationskammer) in Prague. Thus, the multiple letter exchanges between these institutions were the every case's common part. But for the aim of this paper, testimonies of perpetrators are more important.

The centre of Czech early modern historical research is the region of South Bohemia. It is mostly because of the rich archives, which were established in $19^{\text {th }}$ century by members of the nobility, who owned the estate. Members of the Schwarzenberg aristocratic family owned important early modern towns like Český Krumlov, Hluboká nad Vltavou or Třeboň, similarly the house of Černín possessed the nearby locations like Jindřichův Hradec. Therefore, many important documents were preserved and organized in city archives, not only charters or chronicles, but also the evidential and economic sources, like parish registers, account books or judicial agenda. These sources were thoroughly analysed by historians from the Charles university in Prague as well as researches from the University of South Bohemia in České Budějovice. ${ }^{29}$

The judicial sources were written by members of princely office or the members of city council (city fathers), who were dealing with everyday-life problems of the town and the estate, like criminality. Thus, we can examine letter exchange between the officials, testimonies, interrogation proceedings and the crime's descriptions in the judicial collection, which can help us to understand the everyday problems (conflicts) of the marginal people like journeymen or maidservants. ${ }^{30}$ These sources dealing with murders like

29. Člověk a sociální skupina ve společnosti raného novověku, ed. V. Bůžek, České Budějovice 2007; J. Hrdlička, Jindřichohradecké měšt'anky na přelomu 16. a 17. století, Brno 2001; J. Hrdlička, Deníkové záznamy jindřichohradeckého měštana Jiř́́ka Pavlovského z počátku 17. století, "Jihočeský sborník historický" 72 (2003), pp. 137-174; P. Himl, Vrchnost a venkované v myšlení poddanské společnosti na českokrumlovském panství v 17. a 18. století, "Opera historica" 5 (1996), pp. 639660; P. Himl, Zrození vagabunda. Neusedlí lidé v Čechách 17. a 18. století, Praha 2007; P. Matlas, Shovívavá vrchnost a neukáznění poddaní? Hranice trestní disciplinace poddaného obyvatelstva na panství Hluboká nad Vltavou v 17.-18. století, Praha 2011. More also in the footnote no. 15.

30. In the collection State district archive Třeboň, branch office Jindřichův Hradec, estate of Jindřichlv Hradec (Velkostatek Jindřichův Hradec): sign. VBC (zločiny), inv. 
infanticide were written by the judicial scribe in Jindřichův Hradec (between the 1690 and 1710 it was the burgher Matěj Andrýs), who sent copies to the castle. Even though that stories presented by the defendants were shortened, edited by the scribe and sometimes even recorded in different language (German instead of original (zech), it is still very valuable source for historical research. We can cautiously examine defendant's tactics, social relationships and conflicts, many historians were also focusing on gender relations and the close reading (narrative analysis) of these texts. ${ }^{31}$

Five women were investigated for child murder in Jindřichův Hradec between 1690 - 1710. Every process with the Mariána Filipová, Mariána Dalšovská, Voršila Králová, Alžběta Symandlová and Eva Mikšová started with an information brought in by an anonymous witness (who discovered the corpse of the dead baby). The whole process was classified, and it was characterized by a superior power of the city council in Hradec over the defendant. ${ }^{32}$ Although the court undertook investigation and prosecution

č. $4358-4360$ we can find several manuscript boxes with the documents concerning murders (no. 412), cases dealing wit fornication and adultery (413-417), finally in the last five boxes the cases about theft and poaching $(418-421)$. This research follows the study written by Jaroslav Dibelka, who attracted my attention to these sources: J. Dibelka, Obranné strategie "zmrhaných" žen na jindřichohradeckém panství v 17. a na počátku 18. Století, "Historická Demografie" 31 (2007), pp. 5-20.

31. Critical approaches to these sources mentioned: J. Dibelka, $K$ novým možnostem studia trestněprávní problematiky. Obranné strategie mužů a žen obviněných ze smilstva na třeboňském panství (1650-1750), "Český časopis historický" 106 (2008), p. 27; U. Gleixner, "Das Mensch" and "der Kerl“. Die Konstruktion von Geschlecht in Unzuchtsverfahren der Frühen Neuzeit (17oo-176o), Frankfurt-New York 1994, pp. 19-20; D. W. Sabean, Peasant Voices and Bureaucratic Texts: Narrative Structure in Early Modern German Protocols, in: Little Tools of Knowledge. Historical Essays on Academic and Bureaucratic Practices, eds. P. Becker, W. Clark, Ann Arbor 2001, pp. 67-93; Wahrheit, Wissen, Erinnerung: Zeugenverhörprotokolle als Quellen für soziale Wissensbestände in der Frühen Neuzeit, Hrsg. R. P. Fuchs, W. Schulze, Münster-Hamburg-London 2002, pp. 7-40.

32. The legal system of prosecution for infanticide was for the first time described in Constitutio Criminalis Carolina (1532), available, e.g., in a later German/Latin edition: Constitutiones Criminales Caroli V, Magdeburg 1716. However, this law code was only subsidiary for the Czech kingdom, and two other law books were in use (in a Czech edition): Obnovené právo a zř́izení zemské dědičného království Českého, ed. H. Jireček, Praha 1888; K. Malý (et al.), Práva městská Království českého: edice s komentářem, Praha 2013. More about this legal system in broader European context D. Myers, Death and a Maiden..., op. cit., pp. 33-43; M. B. Lewis, Infanticide..., op. cit, pp. 16-49. For the Czech and Moravia context see L. Novotný, Kauza "Abeles". Př́íklad řízení v trestní věci před apelačním soudem na sklonku 17. Století, in: Problematika historických a vzácných knižních fondů Čech, Moravy 
completely on its own initiative, it was supervised by the princely office in local caste and at the same time the consultations with the superior court of appeal in Prague were obligatory.

This sometimes-long-lasting communication could also cause many conflicts. Especially when defendants wrote a supplication for pardon during the trial (like Elisabeth Symandlin did), in which they twisted the facts and questioned the procedure, which resulted in misunderstanding between superior court and the city counsel. Counsel was accused of maltreatment by the women and officials in Prague obviously wanted to know why. Consequently, Elisabeth, who was spending almost two years in prison cell waiting for the verdict, became ill and probably died there. ${ }^{33}$

\section{Family issues - sisters and stepmothers}

It is difficult to say how important the family was for the defendants, but from the phrases like "I was afraid of my people," 34 "I thought I would go home to show them my baby," 35 but "I was afraid my parents would treat me badly." 36 it is apparent that women feared their parents' authority and they were aware of their social situation, as well as the economic consequences of the illegitimate motherhood. ${ }^{37}$ As David Myers argues, "For a single woman of poor means, the signs of pregnancy announced the social and legal troubles she would face as a sinner and an outcast." 38

Records from Elisabeth's Symandlin case indicate, that her very strict sister accused her of being "a god dammed whore." 39 Her stepmother beat and humiliated her, maybe more than once, because she did not behave properly: "My stepmother took a twig and wiped my back heavily, she tore down

a Slezska. Sborník z 17. odborné konference Olomouc, 5.-6. listopadu 2008, Olomouc 2009, pp. 204-205; J. Čechura, Sex v době temna, Praha 2015.

33. More about this in P. Stůj, Gender and Infanticide..., op. cit.

34. Elisabeth, f. 326r.

35. Elisabeth, f. $362 \mathrm{v}$.

36. Elisabeth, f. 328 r.

37. One version of the protocol gives her explanation: "I was afraid of a high fine and of my parents, who would have blamed me and that I would have to prove who the father of that child was. As I said before, I just hoped that if the child was stillborn, it would be better for me because I would not have had to care about it." (Elisabeth, f. 327 r.)

38. D. Myers, Death and a Maiden..., op. cit., p. 86.

39. "You goddammed whore, you did a very 'nice' thing to us once [dishonour Family], you will end up in the cage and then you will stand in the pillory!" (Elisabeth, f. 361r.) 
my headscarf, she slapped me several times and then she griped my neck and throw me backwards." ${ }^{40}$ Elisabeth had more than few conflicts with her female relatives, which could reflect the fact that she was also a stepchild..$^{4}$ In one of her answers, she blamed her stepmother Mandelína for neglecting the household maintenance and questioned the fulfilment of her mothering duties as well: "I quarrelled with her a lot, because she came home late and left her child with strangers." 42 Mandelína, on the other hand, blamed Elisabeth for not showing any respect to her: "She did not care about me, she acted as if she was not obliged to obey her stepmother. So, I was often evicting her from the house to follow her own way." 43

Family relations were probably the reason why later Elisabeth tried to change the inevitable course of events on her own. Already pregnant, she left the family and delivered a child alone in the middle of the night in the distant village.

Some women wanted to escape from the community and yet to stay with their family. This contradiction caused psychological pressure, doubts and hesitation as Elisabeth Symandlin explained: "I was afraid and ashamed, I thought I would rather go to the city, but at the same time I was frightened, because they could be mean to me as they had been before." 44 She was torn between the desire to entrust herself to her family and the effort to protect her honour, to stay away from the community which could discover her pregnancy any time: "Yes, I was afraid that all of them would treat me badly, then I decided I would rather be alone, and I went away." 45 Therefore, some of these cases can be understand also as a problem of intrapersonal conflicts in a very similar way as in pamphlet about melancholy (Blood for Blood).

40. Elisabeth, f. 360v-361r.

41. Maltreatment of stepparents against their children was described by evolutionary biology as a Cinderella effect, however, this thesis is criticised as quite controversial. On defend of this effect see M. Daly, M. Wilson, Is the 'Cinderella Effect' controversial?", in: Foundations of Evolutionary Psychology, edd. C. Crawford, D. Krebs, New York 2007, pp. 383-400.

42. Elisabeth, f. 268r.

43. Elisabeth, f. 297v.

44. Elisabeth, f. 298.

45. Elisabeth, f. 297v. 
Spouses, husbands and fathers

In other cases, we can meet with different types of relationship conflicts. Married woman Mariana Filipová was persuaded by her husband Bartoň to kill their child, because he was afraid of guild restriction: "He asked me, if the baby is alive. I told him, that I am not sure, I did not feel or hear anything. He said, if the baby is not alive, we will burry it in the ground. I am afraid what would your parents say, because they did not know you are pregnant and I will have to pay a fine to the guild and I will lose my trade." 46

According to Marianna, the community's and guild's pressure was the main reason for the infanticide. Mariana seemed to be under the strong influence of her husband, because later she confessed, that she suffocated her child with the pillow (on his insistence). She was sentenced to death and executed, while her husband ran away to Prague.

Similarly, Eva Mikšová, 35-year-old maidservant (the oldest from the five women), had an intercourse with a young boy, seventeen years old Gregor Alt, son of a rich farmer. Obviously, the relationship was problematic, because Gregor's father disagreed with a poor and much older bride for his son. As many other women, Eva did not tell about her pregnancy to anyone, secretly self-delivered a child in the attic. She was discovered later fainting with the dead child on the floor, and she was imprisoned soon after that. ${ }^{47}$

In both cases the authority of husband, spouse (or his father) forced women to be silent. Infanticide was inevitable, because women were afraid of speaking publicly about unwanted pregnancy and they did not want to act against the wish of their husband, the authority of community or a guild.

\section{Housekeepers and employers}

Finally, the fear of losing their job and being punished for sexual crimes led many women like Voršila Králová and Mariána Dalšovská to conceal their relationships and later also to hide their pregnancy. However, having an affair in early modern household was not easy, due to a lack of the privacy, even an extreme secrecy attracted an attention.

Mariána Dalšovská was a waitress, who probably had relationship with two boys at the same time. Her reputation was bad in the town and judges wondered, why her employer, innkeeper Hans Emer, did not intervene. Emer

46. Vs. J. Hradec, inv. č. 436o, kart. 415 (Mariana), f. 65.

47. Eva, f. 148r. 
pointed out that he scolded her many times and beat her too, however, it did not have any effect. Later Mariána blamed him that he knew, but he just did not care, even when they were sleeping in the same bed. Yet, we can see that many everyday conflicts like this continued for months during the investigation, moreover, when Mariana gave a birth to the dead child in the prison cell. ${ }^{4}$

Also, the case of another woman, Voršila Králová, is filled with similar verbal interpersonal conflicts, which sometimes includes verbal abuse as well. Voršila secretly delivered a child early in the morning in June 1702, yet there were three other women in the house, housekeeper, widow Vydrová, and two of her maids. They asked Voršila several times if she is pregnant.

Finally, when Voršila complained about a stomach ache in the morning, maids started to pay more attention to her. One saw Voršila with the hands covered with blood, other had feeling she heard baby crying in the locker. Finally, Mistress commanded Voršila to visit her in the office, asking her directly about her child. Vydrová examined her body and then they had a following argument: Look, you beast, I asked you another day, are you with a child or not and you denied everything, but I know, who you are now! Where is your baby! Give that child to me! But Voršila said: My dear madam, please, for God sake, where would I take a baby? Then, madam ripped her shirt on her chest, because she denied everything over and over again. She took her breast and the milk squirted against her. Why do you have milk? She asked. I am always having milk, Voršila answered. You are always a whore then. ${ }^{49}$ Few minutes after this confrontation, Voršila appeared with the dead baby and was imprisoned by the richter.

\section{Conclusion}

Every woman had a choice to respond to the situation (unwanted pregnancy) as to the any other type of conflicts, she could fight, flee, simply freeze, or turn sideways to the conflict. For instance, some of the perpetrators (both in fictional news and criminal records) fought against the society, they killed the child and did not reveal it, other tried to escape from the community, few of them remained silent and did not do anything, until it was too late. Pregnant women acted like individuals who were seeking for a safe harbour, but

48. Mariána Dalšovská, f. 438r-450v.

49. Voršila Králová, f. 362r. 
their opponents were vigilant. All of them, sexual partners, parents, friends, employers, had their own plans and strategies and having an unmarried mother and her bastard child in the household was not an option for them. Therefore, the controversy erupted, in which both parties were protecting their honour, Christian ideals and future living conditions.

To conclude, in both types of sources, in the early modern street literature and interrogation proceedings, we can notice, that the infanticide was often explained as a result of social conflicts The fictional strife and conflict of impersonal ideals were typical for street literature. These conflicts in pamphlets and broadsheets were clearly moralizing. Marital disagreements about religion, but also about other sins, like gambling, drinking alcohol, having an affair, could lead to the fight between the partners and subsequent murder (of the child or whole family), which were thought the work of the devil. These texts were often presented publicly and therefore they urged people to defend theirs or accuse different religion and served for the confessional propaganda. ${ }^{50}$

The second type of the texts documents interpersonal conflicts between individuals and the community (family, guild, village). On the one hand, they depict emotions, behaviour and social tension in early modern village, on the other hand, these accusation of partners or mothers in protocols can be seen also as a intentionally constructed story, which was made up by defendants. Conflicts in these cases can be nothing more then a result of women's tactics. They blamed their stepmothers for the child death, because they were beating them, blamed their husbands, who persuaded them to do it or other men who promised them marriage and then left them alone.

Nevertheless, in many infanticide cases we can find women, who really were rude and cheeky. They were actively seeking help on their own (Elisabeth Symandlin or Eva Mikšová), they improvised when necessary, and almost succeeded to sweep away the evidence..$^{51}$

50. P. Stůj, Neřádné matky a krutí otcové. Infanticida jako nástroj propagandy v raněnovověké letákové literatuře, "Historica Olomucensia" 52 (2017), pp. 87-112.

51. When we compare her actions to the maidservant Grethe Smidt it is clear that the corpse was the biggest problem and Elisabeth failed to get rid of it. However, even if the body had never been found as in Grethe's case, gossips and accusations would have been enough to start the investigation anyway. D. Myers, Death and a Maiden..., op. cit., pp. 86-97. 
Women's agency was very clear in these cases. Without any doubts, there were not only obedient single women waiting for proper marriages in early modern Bohemia, but also active and stubborn ones, who wanted to solve their problems.

Their stories are still fascinating to us, even though so much have been already written about them. 


\section{Bibliography}

\section{Primary sources}

Anonym, Bloody Newes from Dover. Being a true relation of the great and bloudy murder, committed by Mary Champion, London 1647, Early English Books Online [EEBO], Wing B3267.

Anonym, Dwoge Nowiny: Prwnij Co se w Městě Losanně w Zemi

Ssweycarské ležjcým y při giných Městech, Praha 1589, Knihopis

Ko6486, online: http://www.manuscriptorium.com/apps/index. php? direct=record\&pid=AIPDIG-KCR__65_E_2031_-_49PG508cs\#search (30.03.2019).

Anonym, Mord ukrutný, který se stal v kraji brněnském. Muzem

Komenského v Přerově, sign. J-2698.

Anonym, Nová píseñ, Okolo Dunaje chodila, krásné pachole nosila.

Knihovna národního muzea [KNM], sign. A 2574.

Anonym, Nová píseň o jedné bohaprázdné panně. KNM, sign. KP 3838.

Anonym, Nová píseň. Krkavčí matka. Hrozná vražda malé Růženky. KNM, sign. KP D 34/1.

Anonym, Eine Warhafftige vnd erschröckliche newe zeittung welche sich begeben vnd zugetragen hat in der Stadt Limmburg, Frankfurt am Main 1626 (printer Wolfgang Richter), available in Germanisches Nationalmuzeum, Nürnberg, sign. HB24792.

Beccaria C., An Essay on Crimes and Punnishements, London $1769^{2}$.

Děti roditi jest Božské ovotce: gender a tělo v českojazyčné babické literatuře raného novověku, Praha 2013.

Eld G., A Pittilesse Mother: The at most vnnaturally at one time, murthered two of her owne children at Acton within sixe miles from London vppon holy Thursday, London 1616, EEBO, STC 24757.

Malý K. (et al.), Práva městská Království českého: edice s komentářem, Praha 2013.

Nádoby mdlé, hlavy nemající?: diskursy panenství a vdovství v české literatuře raného novověku?, edd. J. Ratajová, L. Storchová, Praha 2008. 
Obnovené právo a zř́zení zemské dědičného království Českého, ed.

H. Jireček, Praha 1888.

Patridge N., Blood for Blood or Justice executed for innocent Blood-shed. Being a True Narrative of that late Horrid committed by Mary Cook, London 1670, EEBO, Wing, P630.

Sarius J., Infanticidium Helmsdorffianum: Oder: Christliche Leichenund Klagpredigt [...] Uber dem grausamen/ erschrecklichen und unerhörten Kinder Mordt/So sich begeben in der Mühlen zu Helmsdorff, Dreßden 1633, in: Das Verzeichnis der im deutschen Sprachraum erschienenen Drucke des 17. Jahrhunderts, http://www. vd17.de/ (30.03.2019), sign. 3:634234H.

State District Archive of Třeboň: branch office Jindřichův Hradec, in the collection of estate of J. Hradec (fond Velkostatek J. Hradec), Crimes (Zločiny), sign. VBC, cardboard 413-417. In Czech: Státní okresní archiv Třeboň, pobočka Jindřichův Hradec, fond Velkostatek Jindřichův Hradec, signatura VBC (zločiny), inventátní číslo 43584360, karton 413-417.

Žena není příšera, ale nejmilejší stvoření boží: diskursy manželství v české literatuře raného novověku, edd. J. Ratajová, L. Storchová, Praha 2009.

Žádná ženská člověk není: Polarizace genderů v českojazyčné literatuře 18. a 19. století, edd. J. Ratajová, L. Storchová, Praha 2010.

\section{Articles}

Daly M., Wilson M., Is the 'Cinderella Effect' controversial?, in: Foundations of Evolutionary Psychology, edd. C. Crawford, D. Krebs, New York 2007, pp. 383-400.

Dibelka J., K novým možnostem studia trestněprávní problematiky. Obranné strategie mužů a žen obviněných ze smilstva na třeboňském panství (1650-1750), "Český časopis historický" 2008 no. 106, p. 27.

Dibelka J., Obranné strategie "zmrhaných" žen na jindřichohradeckém panství v 17. a na počátku 18. století, "Historická Demografie" 31 (2007), pp. 5-20.

Dibelka J., Tajemství rodiny Hlučných. Obranné strategie žen obviněných z infanticidia, "Dějiny a současnost" 2007 no. 9, pp. 37-39.

Himl P., Vrchnost a venkované v myšlení poddanské společnosti na českokrumlovském panství v 17. a 18. století, "Opera historica" 1996 no. 5, pp. 639-66o. 
Hrdlička J., Deníkové záznamy jindřichohradeckého měšt'ana Jiříka Pavlovského z počátku 17. století, "Jihočeský sborník historický" 72 (2003), pp. 137-174.

Jeremiah E., Murderous Mothers. Adrienne Rich's Of Woman Born and Toni Morrison's Beloved, in: From Motherhood to Mothering: The Legacy of Adrienne Rich's Of Woman Born, ed. A. O'Reilly, New York 2004, pp. 59-71.

Luxová A., Problém infanticidy ve vzorku trestanek $v$ ženské trestnici v Řepích, "Historická Demografie" 29 (2005), pp. 139-200.

Novotný L., Kauza "Abeles". Příklad ř́zení v trestní věci před apelačním soudem na sklonku 17. Století, in: Problematika historických a vzácných knižních fondů Čech, Moravy a Slezska. Sborník z 17. odborné konference Olomouc, 5.-6. listopadu 20o8, ed. R. Krušinský, Olomouc 2009, pp. 204-205.

Obladen M., From Right to Sin: Laws on Infanticide in Antiquity, "Neonatology" 109 (2016), pp. 56-61.

Obladen M., From Sin to Crime: Laws on Infanticide in the Middle Ages, "Neonatology" 109 (2016), pp. 85-90.

Obladen M., From Crime to Disease: Laws on Infanticide in the Modern Era, "Neonatology" 109 (2016), pp. 170-176.

Pánek J., Zločin „zahubení plodu” v Maršovicích roku 1682, “Český lid" 1979 no. 66, pp. 45-46.

Procházková E., Žena a smrt dítěte v soudní praxi raného novověku. Edice a rozbor Čechtického útrpného vyznání z roku 1729, "Sborník vlastivědných prací Podblanicka" 1994 no. 34, pp. 115-128.

Simmel G., The Sociology of Conflict I, "American Journal of Sociology" 9 (1903), pp. 490-525.

Storchová L., Gender a "přrirozený řád”, in: Nádoby mdlé, hlavy nemající?, edd. J. Ratajová, L. Storchová, Praha 2008, pp. 510-530.

Stůj P., Gender and Infanticide in Early Modern Bohemia: The Case of Elisabeth Symandlin, 1707-1710, "West Bohemian Historical Review" 8 (2018) no. 2, pp. 145-184.

Stůj P., Neřádné matky a krutí otcové. Infanticida jako nástroj propagandy v raněnovověké letákové literatuře, "Historica Olomucensia" 52 (2017), pp. 87-112.

Šubrtová A., Kontracepce, aborty a infanticida v pramenech k předstatistickému období, "Historická Demografie" 15 (1991), pp. $9-46$. 
Tinková D., Ilegitimita a "nová ekonomie života“ v osvícenské Habsburské monarchii. Problém svobodných matek a nemanželských dětí mezi sociální kontrolou a sociální péčí na prahu občanské společnosti, "Historická Demografie" 27 (2003), pp. 133-172.

Tinková D., Předcházet či trestat? Problém infanticidia v osvícenské společnosti, "Český časopis historický" 101 (2003), s. 27-76.

Velková A., Dítě jako obět'. Vraždy dětí spáchané jejich matkami ve 2. polovině 19. století, in: Od početí ke školní brašně. Sborník z odborného semináře konaného 29.-3o. května 2008 ve Východočeském muzeu v Pardubicích, ed. M. Halířová, Pardubice 2008, pp. 147-163.

Wieviorka M., Social Conflict, "Current Sociology" 61 (2013) no. 5-6, pp. $696-713$.

Williamson L., Infanticide: An Anthropological Analysis', in: Infanticide and the Value of Life, ed. M. Kohl, New York 1978, p. 61-75.

\section{Secondary sources}

Boes M., Crime and Punishment in Early Modern Germany: Courts and Adjudicatory Practices in Frankfurt am Main, 1562-1696, Farnham 2013.

Čechura J., Kriminalita a každodennost v raném novověku, Jižní Čechy 1650-1770, Praha 2008.

Čechura J., Sex v době temna, Praha 2015.

Člověk a sociální skupina ve společnosti raného novověku, ed. V. Bůžek, České Budějovice 2007.

Dibelka J., Obranné strategie mužů a žen obviněných ze smilstva a cizoložství. Panství Třeboň na přelomu 17. a 18. Století, České Budějovice 2012.

van Dülmen R., Frauen vor Gericht: Kindsmord in der Frühen Neuzeit, Frankfurt a.M. 1991.

Francek J., Zločin a sex v českých dějinách. Manželské spory a sexuální kriminalita v raném novověku, Praha 2000.

Francek J., Dějiny loupežnictva: zloději, loupežníci, lupiči, pytláci a žháři $v$ českých dějinách, Praha 2002.

Gleixner U., "Das Mensch" and "der Kerl". Die Konstruktion von Geschlecht in Unzuchtsverfahren der Frühen Neuzeit (170o-176o), Frankfurt-New York 1994. 
Harrington J., The Unwanted Child: The Fate of Foundlings, Orphans, and Juvenile Criminals in Early Modern Germany, Chicago 2009.

te Heesen K., Das illustrierte Flugblatt als Wissensmedium der Frühen Neuzeit, Opladen 2011.

Himl P., Zrození vagabunda. Neusedlí lidé v Čechách 17. a 18. století, Praha 2007.

Hoffer P., Hull N., Murdering Mothers: Infanticide in England and New England 1558-1803, New York 1981.

Hrdlička J., Jindřichohradecké měšt'anky na přelomu 16. a 17. století, Brno 2001.

Hrdy S. B., Mother Nature. A history of mothers, infants, and natural selection, New York 1999.

Kilday A., A History of Infanticide in Britain, c. 160 o to the Present, Basingstoke 2013.

Lewis M. B., Infanticide and abortion in early modern Germany, New York 2016.

Matlas P., Shovívavá vrchnost a neukáznění poddaní? Hranice trestní disciplinace poddaného obyvatelstva na panství Hluboká nad Vltavou v 17.-18. století, Praha 2011.

Michalik K., Kindsmord, Sozial- und Rechtsgeschichte der Kindstötung im 18. und beginnenden 19. Jahrhundert am Beispiel Preußen, Pfaffenweiler 1997.

Müller W., Die Abtreibung: Anfänge der Kriminalisierung 1140-1650, Cologne 2000.

Müller W., The Criminalization of Abortion in the West: Its Origins in Medieval Law, Ithaca 2012.

Myers D., Death and a Maiden. Infanticide and the Tragical History of Grethe Schmidt, DeKalb 2011.

Nature's Cruel Step-dames: Murderous Women in the Street Literature of Seventeenth Century England, ed. S. Staub, Pittsburgh 2005.

Newborn Child Murder: Women, Illegitimacy and the Courts in Eighteenth-Century England, ed. M. Jackson, New York 1996.

Sabean D. W., Peasant Voices and Bureaucratic Texts: Narrative Structure in Early Modern German Protocols, in: Little Tools of Knowledge. Historical Essays on Academic and Bureaucratic Practices, eds. P. Becker, W. Clark, Ann Arbor, University of Michigan, pp. 67-93.

Schilling M., Bildpublizistik der frühen Neuzeit: Aufgaben und Leistungen des i1ustrierten Flugblatts in Deutschland bis zum 1700, Tubingen 1990. 
Tinková D., Hřích zločina šilenství v čase odkouzlování světa, Praha 2004.

Tinková D., Tělo, věda, stát. Zrození porodnice v osvícenské Evropě, Praha 2010.

Ulbricht O., Kindsmord und Aufklärung in Deutschland, Munich 1990.

Wahrheit, Wissen, Erinnerung: Zeugenverhörprotokolle als Quellen für soziale Wissensbestände in der Frühen Neuzeit, Hrsg. R. P. Fuchs, W. Schulze, Münster-Hamburg-London 2002.

Wiltenburg J., Crime and culture in early modern Germany, Charlottesville 2012.

\section{Websites}

The Cambridge dictionary, https://dictionary.cambridge.org/dictionary/ english/conflict (29.09.2018).

Digital Library of Written Cultural Herritage: http://www. manuscriptorium.com/Tertullianus, Apologeticum, http://www. tertullian.org/other/czech_apologeticum.htm (4.06.2018).

Das Verzeichnis der im deutschen Sprachraum erschienenen Drucke des 17. Jahrhunderts http://www.vd17.de/ 


\section{Abstract}

Pavel Stůj

\section{Infanticide and the Conflicts}

in Early Modern South Bohemia (1690-1710).

Five Women from Jindřichův Hradec

\footnotetext{
Keywords:

infanticide,

conflict, murder,

children,

early modern, proceeding, broadsheet, broadside ballad, crime, women
}

Early Modern Child-Murder Investigations Were Characterized by Many Conflicts and Struggles on Different Levels of the Social Organization. Sources like broadside ballads or pamphlets highlighted the infanticide as a matter of considerable public concern. There the conflict between idea of early modern motherhood and family life and the everyday life of single-mothers dealing with unwanted children was apparent. These moralizing pamphlets were describing virtues of motherhood like self-sacrifice, solicitude, economic and social responsibility and on the other hand authors criticized murdering mothers. Finally, conflicts, antipathy and personal confrontations between members of the family and sexual partners can be traced in these sources. Events prior the crime can be characterized by disagreements between sexual partners, violence and verbal abuse. This contextual analysis of conflicts in five infanticide proceedings from south Bohemia (1690-1710) is the centre of the paper. 


\section{Abstrakt}

Pavel Stůj

Dzieciobójstwo i konflikty

w nowożytnej południowej Bohemii (1690-1710).

O pięciu kobietach z Jindřichův Hradec

Nowożytne śledztwa w sprawie morderstw dzieci charakteryzowały się wieloma konfliktami i walkami na różnych poziomach organizacji społecznej. Źródła, takie jak ballady czy pamflety, publikowane w gazetach dużego formatu, ukazują dzieciobójstwo jako kwestię, którą żywo interesowała się opinia publiczna. Widać było w tym konflikt między nowożytnym ideałem matki i życiem rodzinnym a samotnymi matkami z niechcianymi dziećmi. Moralizatorskie pamflety przywoływały takie cnoty macierzyństwa, jak samopoświęcenie, troska o innych czy ekonomiczna i społeczna odpowiedzialność, jednocześnie krytykując matki dzieciobójczynie. Co więcej, w tych źródłach można doszukać się konfliktów, antypatii i personalnych konfrontacji między członkami rodziny a kochankami. Wydarzenia poprzedzające zbrodnię dzieciobójstwa to przede wszystkim niesnaski między partnerami seksualnymi, przemoc i słowne zniewagi. Przedmiotem niniejszego artykułu jest analiza kontekstualna pięciu spraw sądowych dotyczących dzieciobójstwa, które to postępowania miały miejsce w południowej Bohemii w latach 1690-1710.
Słowa kluczowe: dzieciobójstwo, konflikt, morderstwo, dzieci, postępowanie sądowe, kobiety 